\title{
Stock Valuation of Indonesian Natural Gas Company in the Middle of Global Economic Slowdown
}

\author{
Felix Terahadi, Subiakto Soekarno \\ School of Business Management \\ Institut Teknologi Bandung \\ Bandung, Indonesia \\ felix.terahadi@stb-itb.ac.id.com
}

\begin{abstract}
-2015 is a difficult year as the economic slowed down has made most industries suffer in their core business activities. Nevertheless, Indonesian stated-owned company, PT. Perusahaan Gas Negara (Persero) Tbk (PGN), announced their infrastructure project plan. The project consist of 12 pipelines infrastructure development for distribution and transmission with the total length of $1,685 \mathrm{~km}$. PGN also stated that the project will be funded without burdening the government infrastructure budget. Despite the unconducive economic condition, the analysis shows a bright long-term prospect in natural gas industry indicated by the good demand growth and Indonesia's stable economic growth. The prospect of natural gas industry in Indonesia is also stimulated by President Joko Widodo's megaproject in establishing infrastructure of electric supply for about 35,000 MW with the potential natural gas power plant contribution of $13,649 \mathrm{MW}$. The review has been conducted by using DCF with FCFF, P/E ratio and EV/EBITDA multiple and concluded PGAS's fair price of IDR 4.639,20 with potential upside of $84.8 \%$ from the market price of IDR 2,510 (2 Mei 2016), $\mathrm{P} / \mathrm{E}$ ratio of 12.9 (discount $34.7 \%$ ) which shows the PGN's sentiment in natural gas industry is weak and EV/EBITDA multiple of 8.4 (premium $\mathbf{2 4 . 2 \%}$ ) which shows a PGN's better performance compared to its peer companies. The calculation of optimal capital structure has been conducted and came to the conclusion that PGN is currently in its optimal capital structure.
\end{abstract}

Keywords- economic slowdown, capital market, expansion, valuation

\section{BACKGROUND}

Continuous growth is one of the main hope of the company, even demanded if the company is listed in the stock exchange as an investors are only attracted by the stock of the company that has a good future prospect, indicated by the promising future cash flows. To maintain or even boost the growth, company need to expand their business either horizontally or vertically to meet the growing demand or catch the opportunity of another market segment.

Expansion of the company is considered by pointing to the economic and industrial condition. As in 2015, the global economy slowed down triggered by several factors including China's economy, crisis in Greece, the recovered US economy, shale oil boom and the falling of the crude oil price. This phenomenon affect many aspect of the economy that leads to the instability of global economy and amplify exchange risk.
As the price of oil fall, the price of the alternative energy follows, including coal and natural gas, eroding the company's profitability that have strategic business unit in that sector. Meanwhile, every industries used the energy need to adapt in order to survive in the business as the supply and demand shifting and creating new equilibrium.

"Be Fearful When Others Are Greedy and Greedy When Others Are Fearful", is the quote of one of the most successful investor in the world, Warren Buffett. The quote implies that the opportunities usually appears during the decline, unstable and unpredictable economy. PT Perusahaan Gas Negara (PERSERO) Tbk, PGN, found the global crisis phenomenon as an opportunity to expand their businesses. It is reported that PGN has an expanding plan through their infrastructure that consist of 12 projects including the pipeline for distribution and transmission with total length of $1685 \mathrm{~km}$ for over 4 years, resulting in total of $8656 \mathrm{~km}$ of pipeline by 2019. The expansion is also include the power plant, CNG and LNG systems. All of this infrastructure development will be conducted by PGN without burdening the government spending budget.

Since PGN is a go public company, the data used in the paper is secondary data from various organization such as World Bank, IMF, BPS, Bank of Indonesia, and etc. There is also no exact same method used for valuation since the nature of each industry is different. The previous research, especially valuation, is not available due to the fact that method of valuation can be modified. On the other hand, the modified method is confidential as it is used and kept by the company.

\section{BUSINESS ISSUE EXPLORATION}

\section{A. Conceptual Framework}

In order to achieve robust stock valuation, we first need to understand the business dynamics, conditions and factors that affect the industry. The conceptual framework of this final project is depicted in Fig. 1. 


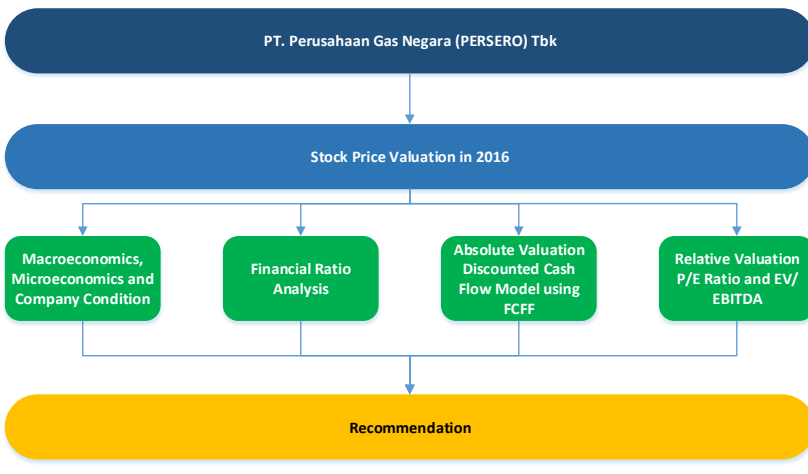

Fig. 1. Conceptual Framework

\section{B. Macroeconomics Analysis}

International Monetary Fund (IMF) forecast that Indonesia's economy is going to grow in the next couple of years indicated by the growth of GDP. GDP growth is followed by higher GDP per capita. Based on this forecast, it is predicted that the growth is not only caused by the proportional growth of the population, every people in Indonesia is estimated to be more productive. Unemployment rate is also gradually decreased due to the growth of economy that resulting in a more demand of the employee. Population of Indonesia is one of the reason of the economic growth as Indonesia is the country with the 4th largest population in the World and it still continue to growth.

In such a growth, Indonesia citizen is expected to have a better household expenditure to meet their daily needs. This prediction is also in line with the forecast of Boston Consulting Group (BCG), well-known statement "people are economy itself" and Indonesia's potential advantages of demography bonus that is going to affect the economy in the next decade from now, reflected in the income and expenditure of the population. From the figure below, it is clear that the growth of expenditure is increased in population of middle class and above from $29.8 \%$ of population in 2012 to $52.7 \%$ of population in 2020 , about $25 \%$ of population moved from low class to middle class.

TABLE I. INDONESIA'S POPULATION AND LEVEL OF PROSPERITY, SOURCE: COMPANY ANNUAL REPORT 2014

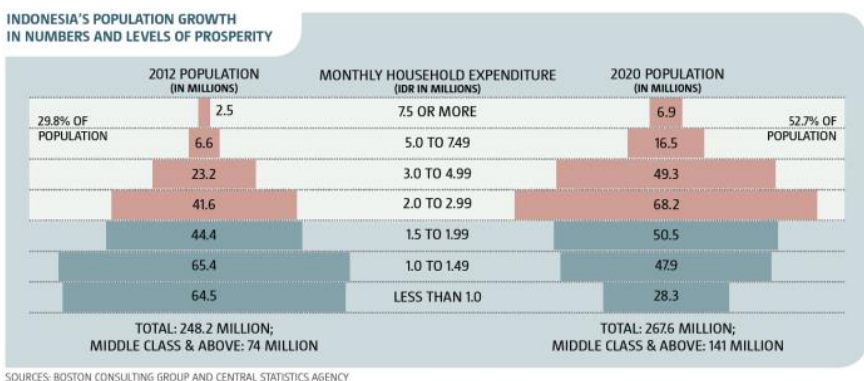

The economy of Indonesia started to recover from the slowed down of the economy in 2015, showed in the Jakarta Composite Index that has already recovered from its lowest level about 4000 to 4800 . The recovery of the economy cannot be separated from the economy policy that has been released by President Ir Djoko Widodo from the fiscal policy side and Bank Indonesia as a central bank of Indonesia from the monetary policy. Currently Bank Indonesia keep stimulating the recovery by targeting the prime lending rate to be reduced from double digit to single digit. This effort is conducted by the monetary policy of $\mathrm{BI}$ rate decreased from $75 \mathrm{bps}$ from $7.5 \%$ to $6.75 \%$ in 3 month started from December 2015. Bank Indonesia also decreased the rupiah denominated primary reserve requirement (giro wajib minimum, GWM) 150 bps from $8 \%$ to $6.5 \%$ in 4 month started from November 2015. The decrease of GWM is also under the Bank Indonesia's consideration that the Banks started to have a better liquidity. In conclusion, the Bank Indonesia tries to stimulate the economy by reducing the cost of debt, triggering the corporate, retail, and micro company to lend money from the bank.

The template is used to format your paper and style the text. All margins, column widths, line spaces, and text fonts are prescribed; please do not alter them. You may note peculiarities. For example, the head margin in this template measures proportionately more than is customary. This measurement and others are deliberate, using specifications that anticipate your paper as one part of the entire proceedings, and not as an independent document. Please do not revise any of the current designations.

\section{Microeconomics Analysis}

\section{1) Natural Gas Industry}

Natural gas is one of three (oil, coal and natural gas) source of energy used in many sectors. According to Central Intelligence Agency (CIA), Indonesia's proven natural gas reserves is rank 12th by 2014, accounted for about 3 trillion cubic meter or 104 TSCF. This data is also in line with the data from ministry of energy and mineral resources of republic of Indonesia. Furthermore, the data shows that the reserves is exclude the potential reserves accounted for 47 TSCF, unconventional gas such as CBM (Coalbed Methane) and shale gas, accounted for $453 \mathrm{TSCF}$ and $564 \mathrm{TSCF}$ in 2012. This data shows that Indonesia is one of the most potential country in the natural gas industry.

Data from ministry of energy and mineral resources of republic of Indonesia shows that natural gas usage is dominated by power plant and industry. The trend of substitute from another energy to natural gas is keep rising as it is started to be considered as the most energy-efficient and environmental friendly. Ministry of Energy Mineral Resources projected the consumption of natural gas in Indonesia.

\section{2) Supply and Demand}

The Demand of energy is in uptrend, the reason behind it is that the world keeps growing. The growth currently driven by developing country with relatively stable and high rate. The forecasted data published by World Bank, Global Economic Prospect 2016, shows that after economy recession in 2015, the growth of developing countries is mainly contributed by East Asia Pacific and South Asia. 
Furthermore, three of four biggest country by population is concentrated in East Asia Pacific and South Asia: China, India, and Indonesia with total population about 2.9 billion people (41.6\% of world population). With such a growth and population, East Asia Pacific and South Asia will demand more energy to accommodate this high growth.

Ministry of Energy and Mineral Resources published the data of supply and demand of the natural gas and its forecast in Indonesia shows in figure below. The data shows that Indonesia's supply cannot meet the domestic demand of natural gas. This imply that the prospect of natural gas industry in Indonesia is promising. On the other hand, the data also shows that export market for Indonesia is potential with the contribution of almost $50 \%$ of the production (exclude the losses of the gas of $8.6 \%$ from total production).

The opportunity is even bigger by the fact that President Joko Widodo planned to establish the infrastructure of power plant with total power of $35,000 \mathrm{MW}$, the plan is expected to be done in 2024. The data published by PT. PLN (PERSERO) shows that power plant with potentially use natural gas as its fuel is accounted for 13,649 of 35,000 MW. This shows that the long-term prospect of natural gas industries is bright.

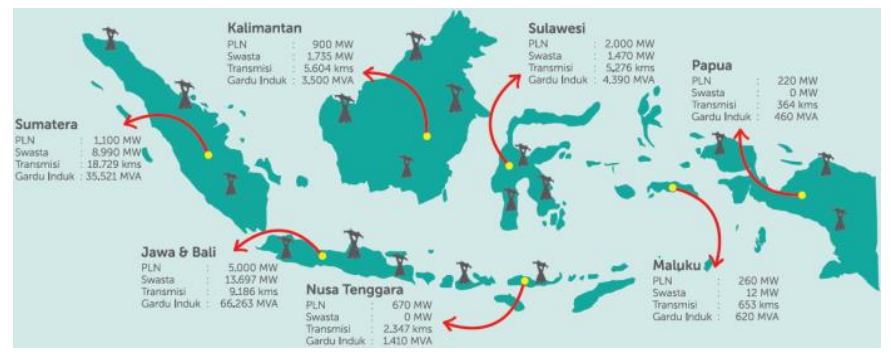

Fig. 2. Electricity Distribution and Transmission Networks Plan, Source: PLN

\section{Financial Ratio Analysis}

For the purpose of measuring PGAS financial performance, Gazprom and Singapore Power Company has been chosen to be its peer. The reason is because Gazprom is one of the biggest natural gas company and Singapore Power as utility company located in Singapore, the same region with Indonesia [1].

- Liquidity Ratios: PGAS's liquidity ratio is fluctuated, starting with the very good liquidity ratio from 2011 to 2012. In 2013 the liquidity of PGAS has fallen significantly by about half. But in 2014 its liquidity is recovered and stable in 2015. Among its peers, PGAS's liquidity ratio is considered good.

- Activity Ratios: PGAS can be considered mediocre as shown in its fixed asset turnover and NWC turnover. But PGAS need to pay attention to their account receivable as it is far below peers. PGAS has relatively big account receivable indicated by low account receivable turnover and low fixed asset turnover while at the same time has high total assets turnover.
- Debt Ratios: From the data of debt ratios, PGAS debt can be considered highest with the lowest interest coverage ratio. This is imply that PGAS currently burdened by high risk. PGAS is gradually increase their financial leverage showed from the debt ratio that gradually increased and the debt to equity ratios that has substantial increase in 2014 and 2015. This is due to the issuance of bonds that is needed to funding the expansion plan. And as a result, the interest coverage ratio reached to the lowest level over the past 5 years. But given the debt ratio of 0.53 , and interest coverage ratio of 4.75 , it can be concluded that PGAS is still at a good and safe condition.

- Profitability Ratios: From the calculation of profitability ratios, it can be concluded that PGAS has the least efficient among peers. Nevertheless, the ROA and ROE of PGAS is relatively good, meaning that PGAS utilize their assets and equity in the right way. For PGAS itself, all ratios indicated the same downtrend, this is the sign that the business is under pressure especially from either the increase of the COGS or decrease in selling price. The symptom is indicated by the gross profit margin that significantly getting lower and lower but at the same time the ratio of SG\&A/sales also getting lower and lower, meaning that the SG\&A resource is getting more efficient from year to year.

- Market Ratios: the market expect PGAS to be in the price on certain PER and Earning yield which respectively over 13 and $8 \%$. This expectation and sentiment makes the PBV ratios looks depended to the PER and earning yield.

\section{BUSINESS SOLUTION}

There are two valuation model, absolute and relative valuation model. Absolute valuation model is a model that specifies an asset's intrinsic value while relative valuation estimates an asset's value relative to that of another asset. Valuation of PGAS uses both absolute valuation and relative valuation. For absolute valuation, the model used is discounted cash flow model. For relative valuation, the model used is PBV, EBITDA multiple and PER. All of the valuation will be elaborated in the sub-section.

\section{A. Absolute Valuation Model}

Free cash flow to firm method is chosen as the valuation is emphasized to focus more on the firm's business with threestage model:

- Phase 1: high capital expenditure to meet the forecasted delivery volume in 2019 of 1902 MMSCFD with the trade-off of lower utilization rate of the pipeline assets and generate low free cash flow.

- Phase 2: improving the efficiency by increasing the utilization rate and low capital expenditure, and generate high free cash flow.

- $\quad$ Phase 3: mature phase with low terminal growth rate. 
Weighted cost of capital (WACC) is a model to determine the riskiness of the estimated cash flows. The WACC is given by:

$$
W A C C=\left(W_{d}\right)\left[k_{d}(1-t)\right]+\left(W_{c e}\right)\left(k_{c e}\right)
$$

The cost of debt $(\mathrm{Kd})$ is initiated by the finding every debt available in the financial statement, the summary of the debt is as follows:

TABLE II. DETAIL OF DEBT (2015)

\begin{tabular}{|ccc|}
\hline \multicolumn{1}{c}{ Type of Debt } & Amount (mn USD) & effective Interest rate \\
\hline Total ST Loan & 0 & - \\
Total LT Debt & $2,708.8$ & $3.79 \%$ \\
LT loans & $1,375.0$ & $2.49 \%$ \\
\hline LT loans (<1yr) & 121.6 & \\
\hline LT loans (>1yr) & $1,253.4$ & $4.92 \%$ \\
\hline Bond (5.125\%, 16 Mei 2024) & $1,333.8$ & \\
\hline
\end{tabular}

TABLE III. COST OF DEBT (IN MN USD)

\begin{tabular}{|c|c|}
\hline \multicolumn{2}{|c|}{ Cost of Debt } \\
\hline Total debt & $\mathbf{2 7 0 8 . 8}$ \\
\hline Bond rate & $4.92 \%$ \\
\hline Rate OLT debt & $2.49 \%$ \\
\hline W bond & $49.2 \%$ \\
\hline W OLT debt & $50.8 \%$ \\
\hline Cost of debt & $\mathbf{3 . 6 9 \%}$ \\
\hline
\end{tabular}

The cost of equity $\left(\mathrm{K}_{\mathrm{e}}\right)$ is calculated using capital asset pricing model (CAPM). The CAPM is calculated by formula blow:

$$
K_{c}=R F R+\beta\left[E\left(R_{m}\right)-R F R\right]
$$

The beta used is beta of PGAS. The value of beta is obtained by gathering the historical weekly price of PGAS and the value of IHSG from 2003 - 2015, then regression linier method is used and beta of 1.07 is obtained.

For the Kc calculation, beta of 1.07, Equity risk premium of $9.65 \%$, and risk-free of rate $7.43 \%$ is used. Both equity risk premium and risk-free rate data is obtained from Damodaran table (February 2016).

Using all of the data above, the calculation of CAPM can be executed as is shown in Table III.4, the result is $17.7 \%$

TABLE IV. COST OF EQUITY (IN MN USD)

\begin{tabular}{|l|r|}
\hline \multicolumn{2}{|c|}{ Cost of Equity } \\
\hline Total equity & 3022.8 \\
\hline $\boldsymbol{\beta}$ (Beta) & 1.07 \\
\hline ER premium & $9.65 \%$ \\
\hline Risk-free rate & $7.43 \%$ \\
\hline CAPM & $\mathbf{1 7 . 7} \%$ \\
\hline
\end{tabular}

And finally the calculation of WACC can be executed, the calculation is as follows:
TABLE V. Weighted-Average Cost of CAPITAL

\begin{tabular}{|l|r|}
\hline \multicolumn{2}{|c|}{ WACC } \\
\hline Tax rate & $25 \%$ \\
\hline $\mathbf{W}_{\mathrm{d}}$ & 0.47 \\
\hline $\mathbf{W}_{\mathrm{e}}$ & 0.53 \\
\hline $\mathbf{C}_{\mathrm{d}}$ & $3.69 \%$ \\
\hline $\mathrm{C}_{\mathrm{e}}$ & $17.7 \%$ \\
\hline WACC & $\mathbf{1 0 . 6 6 \%}$ \\
\hline
\end{tabular}

The tax rate value is based on the corporate tax rate in Indonesia. The basic formula of the FCFF and value of equity is as follows:

$$
\begin{aligned}
& \text { Value of firm }=\sum_{t=1}^{t=0} \frac{F_{C F F_{t}}}{(1+W A C C)^{t}}+\frac{\frac{F C F F_{n+1}}{\left(W A C C-g_{n}\right)}}{(1+W A C C)^{n}} \\
& \text { FCFF }=\text { EBIT }(1-t)-\text { net capex }- \text { change NWC } \\
& \text { Value of equity }=\text { Value of firm }+ \text { Cash }- \text { Debt } \\
& \text { (5) }
\end{aligned}
$$

All free of the valuation use assumption from various source, mostly from World Bank and Bank Indonesia, shown below:

TABLE VI. ASSUMPTION USED IN VALUATION

\begin{tabular}{|l|r|}
\hline \multicolumn{2}{|c|}{ Parameter } \\
\hline Inflation rate & $1.52 \%$ \\
\hline Economic growth & $5.61 \%$ \\
\hline Terminal growth & $3.10 \%$ \\
\hline FX rate assumption & $13,300.0$ \\
\hline Number of shares (mn) & $24,241.5$ \\
\hline
\end{tabular}

By using all of historical data and forecast data, the valuation calculation is conducted and the result is as follows:

TABLE VII. DCF VALUATION

\begin{tabular}{|l|r|}
\hline Firm value & $10,058.4$ \\
\hline Cash & 832.4 \\
\hline Debt & $(2,435.1)$ \\
\hline Intrinsic value (mn USD) & $8,455.7$ \\
\hline Price of shares (USD) & 0.35 \\
\hline Price of shares (IDR) & $4,639.2$ \\
\hline Potential upside & $84.8 \%$ \\
\hline
\end{tabular}

\begin{tabular}{|l|r|}
\hline Valuation Result & $4,639.2$ \\
\hline RHB Bank (9Aug2016) & 3,500 \\
\hline Morgan Stanley (2Aug2016) & 3,800 \\
\hline
\end{tabular}

Sensitivity analysis is conducted to minimize the risk of every unexpected outcome. The discounted cash flow valuation is conducted by assuming several variable as a base of calculation. This assumption may not be accurate and resulting the unexpected outcome. Due to minimize the risk caused by inaccuracy of making assumption, the assumed variable needs to be determine along with its standard deviation. Monte Carlo simulation is chosen to deliver the robust recommendation of 
the stock. Monte Carlo simulation is methodology that simulates a range of possible outcome for the multiple variables determining the intrinsic value of PGAS's stock price. The simulation is run 1,000,000 times and the result is shown in Fig. 3 and Table VIII. Based on this simulation, the mean level of the target price is IDR 4,438.3/share with confidence level of $78.98 \%$ which confirmed our buy recommendation of IDR 4,639.2/shares

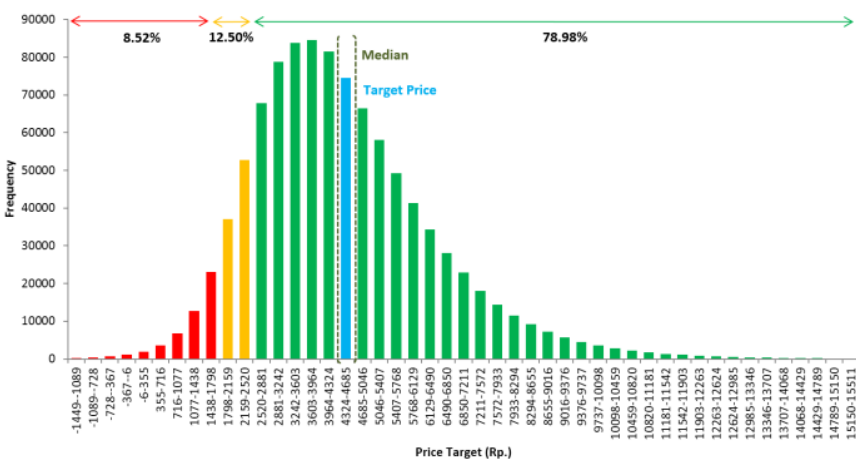

Fig. 3. Monte Carlo Simulation)

TABLE VIII. MONTE CARLO STATISTICS

\begin{tabular}{|l|r|}
\hline \multicolumn{2}{|c|}{ Simulation Statistics (Rp.) } \\
\hline Mean & $4,438.3$ \\
\hline SD & $1,993.7$ \\
\hline 25th Percentile & $3,072.9$ \\
\hline Median & $4,153.8$ \\
\hline 75th Percentile & $5,497.4$ \\
\hline
\end{tabular}

For relative valuation, $\mathrm{P} / \mathrm{E}$ ratio and EV/EBITDA is used. The reason of choosing the both of the ratio is to give an investor an insight whether the stock is good or bad both by focusing on both the market sentiment that fluctuate the price and the performance of the company.

$$
\begin{aligned}
\text { P } / \text { E ratio } & =\frac{\text { Price of stock }}{\text { EPS }} \\
\text { EV } / \text { EBITDA } & =\frac{\text { Entreprise value }}{\text { EBITDA }}
\end{aligned}
$$

TABLE IX. P/E RATIO

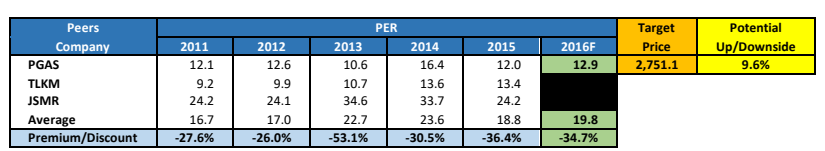

The calculation is started by collecting net income and price of the stock at the end of year for each stock. The next step is calculate every $\mathrm{P} / \mathrm{E}$ ratio for every stock and every year. After that, the $\mathrm{P} / \mathrm{E}$ ratio is then averaged and the result is used to determine the premium/discount compared to the $\mathrm{P} / \mathrm{E}$ of PGAS. Each year's premium/discount is then averaged and used for forecasting the PGAS P/E ratio in 2016F. Based on the
P/E calculation, PGAS is in discount of $34.7 \%$ with the target price is IDR 2,751.1 and $9.6 \%$ potential upside.

For the EV/EBITDA ratio, the method is the same as forecasting the $\mathrm{P} / \mathrm{E}$ ratio. The calculation is shown in Table $\mathrm{X}$ and the result is PGAS has a premium of $24.2 \%$ with the target price of IDR 3,233.10 and $28.8 \%$ potential upside is obtained.

\begin{tabular}{|c|c|c|c|c|c|c|c|c|}
\hline \multirow{2}{*}{$\begin{array}{c}\text { Peers } \\
\text { Company }\end{array}$} & \multicolumn{6}{|c|}{ EV/EBITDA } & \multirow{2}{*}{$\begin{array}{l}\text { Target } \\
\text { Price }\end{array}$} & \multirow{2}{*}{$\begin{array}{c}\text { Potential } \\
\text { Up/Downside }\end{array}$} \\
\hline & 2011 & 2012 & 2013 & 2014 & 2015 & $2016 \mathrm{~F}$ & & \\
\hline PGAS & 7.8 & 10.1 & 8.4 & 11.2 & 4.6 & 8.3 & $3,207.0$ & $27.8 \%$ \\
\hline TLKM & 5.0 & 5.2 & 6.6 & 6.6 & 6.6 & & & \\
\hline JSMR & 7.4 & 7.6 & 7.1 & 9.7 & 5.4 & & & \\
\hline Average & 6.7 & 7.6 & 7.4 & 9.2 & 5.6 & 7.3 & & \\
\hline Premium/Discount & $16.2 \%$ & $32.2 \%$ & $14.0 \%$ & $22.2 \%$ & $-16.8 \%$ & $13.6 \%$ & & \\
\hline
\end{tabular}

TABLE $X . \quad$ EV/EBITDA

With the current $\mathrm{P} / \mathrm{E}$ ratio, the target price of IDR 2751.1 with potential upside of $9.6 \%$ will only resulting the HOLD recommendation. On the other hand, the EV/EBITDA's target price is IDR 3,233.1 with potential upside of $28.8 \%$ which still meet the BUY recommendation. The number may look inconsistent, but knowing that the peer is not in the same industry make the forecast understandable. The $\mathrm{P} / \mathrm{E}$ ratio component is the price of the stock and net income. For the net income, it is exactly reflect the company's performance which is still in line the criteria of choosing the utility company, but price of the stock is fluctuate because of both valuation and market sentiment. From this point, it is clear that PGAS is from energy sector which is currently pressured by the negative sentiment from the falling down of crude oil price an economic recession. On the other hand, TLKM is telecommunication sector which is now known to be one of the growing sector as the digitalization is currently on fire and JSMR is infrastructure sector which currently being focused by government to grow shown by the government expenditure allocation for infrastructure budget.

While the forecast of $\mathrm{P} / \mathrm{E}$ ratio looks a little bit contradict to the absolute valuation, the EV/EBITDA still in line with BUY recommendation threshold, as the characteristic of ratio on $\mathrm{EV}$ is reflecting both sentiment (market capitalization) and performance (debt and cash). EBITDA is also reflect the performance as EBITDA is ignoring the interest expense of the debt which may vary given that the interest rate is depend on many factor, tax rate that also may different from the chosen peer since the natural gas industry is regulated differently and depreciation/amortization which may be different since the fixed assets and the patent (if any) of every industry is different, along with its depreciation period and method. From the calculation, the EV/EBITDA ratio shows that PGAS's company performance is good compared to the other chosen peer, meaning that the valuation is also support the absolute valuation.

Optimal capital structure is conducted to give an insight about the way company structured its capital. The optimal capital structure involve WACC with unlevered and levered beta; and firm value. According to Lawrence J. Gitman in Principles of Managerial Finance (2012), optimal capital structure is examined by finding the basic financial relationship and find the optimal capital structure where the firm value is maximize while at the cost of capital is minimize. 


\section{Asuneses PRESS}

The first step for calculating the cost of equity is by unlevering the beta. This is conducted do to the beta obtained by linier regression is associated with certain capital structure. Therefore, the beta must be adapted with the appropriate capital structure. The formula for unlever and reliever beta is as follows:

$\llbracket \beta$ eta $\rrbracket$ levered $=\llbracket \beta$ eta $\rrbracket$ (unlevered) $[1+(1-\operatorname{tax}) \mathrm{D} / \mathrm{E}](8)$

From the formula, the calculation is summarized below:

TABLE XI. BETA CALCULATION

\begin{tabular}{|c|c|c|c|c|}
\hline Levered Beta & Tax Rate & Debt & Equity & Unlevered Beta \\
\hline 1.07 & $25.0 \%$ & 2708.8 & 3022.8 & 0.64 \\
\hline
\end{tabular}

After the unlevered beta is obtained, the calculation of cost of equity can be conducted by calculating certain combination of debt and equity portion and using CAPM formula with the same assumption of risk-free rate $(9.65 \%)$ and equity risk premium $(7.43 \%)$.

For cost of debt calculation, the author decide to use the bond rating as the milestone and assume that all of the debt structure is the same with the financial statement 2015. The calculation use bond rating from Damodaran January 2016. Since the bond rate's formulation is risk-free rate plus spread, the author assume that the risk-free rate used is $3.375 \%$. The assumption comes from the current bond rate of $5.125 \%$ minus bond rating spread (A3/A-) of $1.75 \%$, resulting of $3.375 \%$ riskfree rate. The interest expenses is also calculated proportionally with the current 2015 capital structure as the reference.

Finally, after of the cost of equity and cost of debt has been calculated, WACC and Firm Value can be calculated

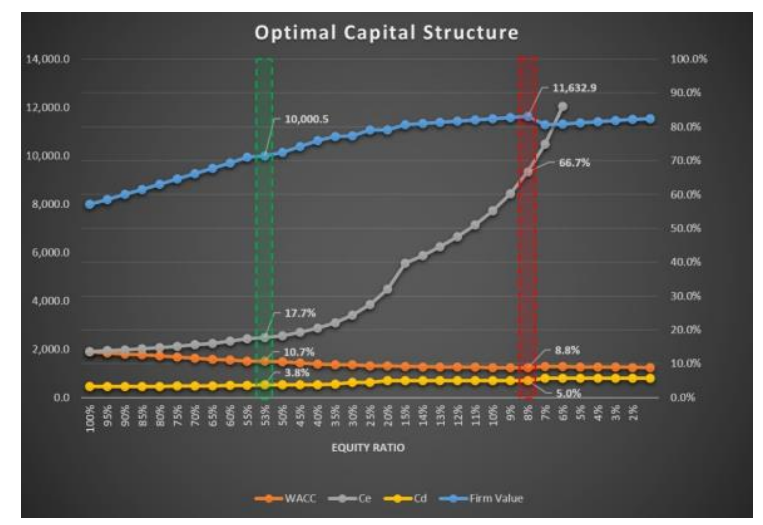

Fig. 4. Optimal Capital Structure

The green highlight is the current capital structure while the red highlight is the optimal capital structure based from the calculation alone. But by considering all of the constraints, PGAS is currently at the optimal capital structure with the note that they should increase the debt service ratio as it would become a problem if it is not meet by company. The detailed calculation and constraint is shown in table below.

\begin{tabular}{|c|c|c|c|c|c|c|c|}
\hline \multicolumn{4}{|c|}{ Optimal Capital Structure Variable } & \multirow{2}{*}{$\begin{array}{c}\text { Debt } \\
\text { Service } \\
\text { Ratio }\end{array}$} & \multirow{2}{*}{$\begin{array}{c}\text { Debt } \\
\text { to } \\
\text { EBITDA }\end{array}$} & \multirow{2}{*}{$\begin{array}{c}\text { Debt } \\
\text { to } \\
\text { Equity } \\
\text { Ratio }\end{array}$} & \multirow{2}{*}{$\begin{array}{c}\text { Interest } \\
\text { Coverage } \\
\text { Ratio }\end{array}$} \\
\hline We & Wd & WACC & Firm Value & & & & \\
\hline $100 \%$ & $0 \%$ & $13.6 \%$ & $7,996.8$ & N/A & 0.0 & 0.00 & 100000.00 \\
\hline $95 \%$ & $5 \%$ & $13.3 \%$ & $8,196.1$ & 11.83 & 0.4 & 0.05 & 55.50 \\
\hline $90 \%$ & $10 \%$ & $12.9 \%$ & $8,401.3$ & 5.92 & 0.8 & 0.11 & 27.75 \\
\hline $85 \%$ & $15 \%$ & $12.6 \%$ & $8,612.7$ & 3.94 & 1.2 & 0.18 & 18.50 \\
\hline $80 \%$ & $20 \%$ & $12.3 \%$ & $8,830.5$ & 2.96 & 1.6 & 0.25 & 13.88 \\
\hline $75 \%$ & $25 \%$ & $12.0 \%$ & $9,038.6$ & 2.37 & 2.0 & 0.33 & 11.10 \\
\hline $70 \%$ & $30 \%$ & $11.7 \%$ & $9,257.9$ & 1.97 & 2.4 & 0.43 & 9.25 \\
\hline $65 \%$ & $35 \%$ & $11.4 \%$ & $9,490.4$ & 1.69 & 2.8 & 0.54 & 7.93 \\
\hline $60 \%$ & $40 \%$ & $11.1 \%$ & $9,713.0$ & 1.48 & 3.2 & 0.67 & 6.94 \\
\hline $55 \%$ & $45 \%$ & $10.8 \%$ & $9,956.9$ & 1.31 & 3.7 & 0.82 & 6.17 \\
\hline $53 \%$ & $47 \%$ & $10.7 \%$ & $10,000.5$ & 1.25 & 3.8 & 0.90 & 5.87 \\
\hline $50 \%$ & $50 \%$ & $10.5 \%$ & $10,133.9$ & 1.18 & 4.1 & 1.00 & 5.55 \\
\hline $45 \%$ & $55 \%$ & $10.2 \%$ & $10,382.8$ & 1.08 & 4.5 & 1.22 & 5.05 \\
\hline $40 \%$ & $60 \%$ & $9.9 \%$ & $10,638.9$ & 0.99 & 4.9 & 1.50 & 4.63 \\
\hline $35 \%$ & $65 \%$ & $9.7 \%$ & $10,798.4$ & 0.91 & 5.3 & 1.86 & 4.27 \\
\hline $30 \%$ & $70 \%$ & $9.7 \%$ & $10,831.8$ & 0.85 & 5.7 & 2.33 & 3.96 \\
\hline $25 \%$ & $75 \%$ & $9.4 \%$ & $11,076.5$ & 0.79 & 6.1 & 3.00 & 3.70 \\
\hline $20 \%$ & $80 \%$ & $9.4 \%$ & $11,061.6$ & 0.74 & 6.5 & 4.00 & 3.47 \\
\hline $15 \%$ & $85 \%$ & $9.2 \%$ & $11,295.6$ & 0.70 & 6.9 & 5.67 & 3.26 \\
\hline $14 \%$ & $86 \%$ & $9.1 \%$ & $11,343.0$ & 0.69 & 7.0 & 6.14 & 3.23 \\
\hline $13 \%$ & $87 \%$ & $9.1 \%$ & $11,390.8$ & 0.68 & 7.1 & 6.69 & 3.19 \\
\hline $12 \%$ & $88 \%$ & $9.0 \%$ & $11,438.7$ & 0.67 & 7.1 & 7.33 & 3.15 \\
\hline $11 \%$ & $89 \%$ & $9.0 \%$ & $11,486.9$ & 0.66 & 7.2 & 8.09 & 3.12 \\
\hline $10 \%$ & $90 \%$ & $8.9 \%$ & $11,535.3$ & 0.66 & 7.3 & 9.00 & 3.08 \\
\hline $9 \%$ & $91 \%$ & $8.9 \%$ & $11,584.0$ & 0.65 & 7.4 & 10.11 & 3.05 \\
\hline $8 \%$ & $92 \%$ & $8.8 \%$ & $11,632.9$ & 0.64 & 7.5 & 11.50 & 3.02 \\
\hline $7 \%$ & $93 \%$ & $9.2 \%$ & $11,283.9$ & 0.64 & 7.6 & 13.29 & 2.98 \\
\hline $6 \%$ & $94 \%$ & $9.1 \%$ & $11,327.1$ & 0.63 & 7.6 & 15.67 & 2.95 \\
\hline $5 \%$ & $95 \%$ & $9.1 \%$ & $11,370.5$ & 0.62 & 7.7 & 19.00 & 2.92 \\
\hline $4 \%$ & $96 \%$ & $9.0 \%$ & $11,414.1$ & 0.62 & 7.8 & 24.00 & 2.89 \\
\hline $3 \%$ & $97 \%$ & $9.0 \%$ & $11,457.9$ & 0.61 & 7.9 & 32.33 & 2.86 \\
\hline $2 \%$ & $98 \%$ & $8.9 \%$ & $11,501.9$ & 0.60 & 8.0 & 49.00 & 2.83 \\
\hline $1 \%$ & $99 \%$ & $8.9 \%$ & $11,546.1$ & 0.60 & 8.0 & 99.00 & 2.80 \\
\hline
\end{tabular}

Fig. 5. Optimal Capital Structure Constraint

\section{CONCLUSION}

Given the all of the analysis and calculation result, the recommendation is made for the investors. As the every threshold for the recommendation vary among financial organization, the author decide to use the CFA research competition standard for giving the recommendation of captured price $\pm 15 \%$ for hold, minus more than $15 \%$ for sell and plus more than $15 \%$ for buy. By referring to the threshold and the assumption of IDR/USD exchange rate of IDR 13,300, the author give buy recommendation for the PGAS stock price with the target price of IDR 4,639.20 and potential upside of $84.8 \%$. This target price is also supported by the Monte Carlo simulation with the certainty of $78.98 \%$. P/E ratio and EV/EBITDA multiple also shows some potential upside of $9.6 \%$ and $28.8 \%$. The P/E ratio of PGAS shows a discount among selected peers of $34.7 \%$ because the energy industries is relatively has more negative sentiment compared to the peer companies who are in different industries. Nevertheless, the EV/EBITDA multiple shows that PGAS is premium compared to peer companies, meaning that PGAS's performance is basically better among peers. 


\section{ACKNOWLEDGMENT}

The author thank to Jesus Christ because of His graces and guidance, this paper can be finished as a requirement to complete the Master of Business Administration Program at Schools of Business and Management, Bandung Institute of Technology with predicate cum laude. The author hopes that the result of this paper can be useful for any investor of PT. Perusahaan Gas Negara (PERSERO) Tbk. in completing this paper, many difficulties arise. However, by the help of various parties, all of these difficulties can be overcome so that the final project can be completed. On this opportunity, the author would like to thank those who have provided guidance, advice, pray, and encouragement especially for Mr. Dr. Subiakto Soekarno MBA, RFA, QWP, CFP as a Counselors and Author's beloved parents

\section{REFERENCES}

[1] Pinto, J. E., Henry, E., Robinson, T. R., \& Stowe, J. D. (2010). Equity Asset Valuation, Second Edition. Hoboken, New Jersey: John Wiley \& Sons, Inc.

[2] Bodie, Z., Kane, A., \& Marcus, A. J. (2013). Essentials of Investments, Ninth Edition. Avenues of Americas, New York: McGraw-Hill Irwin.

[3] CNN Money, 2015, IMF World Economic Outlook., October 2015, Viewed 23 May, 2016 from http://money.cnn.com/2015/10/06/ news/economy/imf-world-economic-outlook/

[4] Damodaran, A. (2012). Investment Valuation, Third Edition. Hoboken, New Jersey: John Wiley \& Sons, Inc.

[5] Gitman, J., Zutter, J. (2012). Principles of Managerial Finance, 13th Ed., Boston, MA: Pearson.

[6] Pusat Data dan teknologi Informasi ESDM, 2014, Kajian Substitusi Gas Dengan Energi Lain Pada Sektor Industri, Desember, 1:12

[7] Ross, S. A., Westerfield, R. W., \& Jaffe, J. (2010). Corporate Finance, Ninth Edition. Avenue of the Americas, New York: McGraw-Hill/Irwin.

[8] The Economist, 2015, World GDP., June 2015, Viewed 23 May, 2016, from http://www.economist.com/news/economic-and-financial-indicator s/21654018-world-gdp

[9] World Bank Group Flagship Report, 2016, Global Economic Prospects: Spillovers amid Weak Growth, January, 1:4 